\title{
Occupationally related angiosarcoma of the liver in the United Kingdom 1972-1994
}

\author{
F I Lee, P M Smith, B Bennett, D M J Williams
}

\begin{abstract}
Background-Angiosarcoma of the liver (ASL) has been described in vinyl chloride workers worldwide.

Aim-To describe the UK experience of occupationally related ASL.

Patients-Twenty patients who died from ASL after exposure to vinyl chloride.

Methods-The case records and pathological findings of these 20 patients were reviewed.
\end{abstract}

Results-Twenty men in the United Kingdom aged 37 to 71 years have developed ASL in association with occupational exposure to vinyl chloride monomer VCM in two factories. All had been exposed to VCM for three to 29 years, the tumour developing nine to 35 years after first exposure. Presenting clinical features included abdominal pain, malaise, jaundice, ascites, and massive hepatomegaly. In most cases the disease progressed rapidly, death occurring within a few weeks from hepatic coma. In 17 cases there was no spread outside the liver. In four cases there had been haemorrhage from oesophageal varices due to noncirrhotic portal fibrosis diagnosed six to 18 years previously. At necropsy the livers of these men showed considerable, often massive, replacement by tumour, apparently multifocal, with necrosis and haemorrhage.

Conclusions-In view of the long latency between exposure and development of the tumour the full extent of ASL occurrence may not be known until 35 years after the introduction of the Code of Practice in 1975.

(Gut 1996; 39: 312-318)

Keywords: vinyl chloride, occupational tumour, liver, angiosarcoma.

Department of Medicine, Llandough

Hospital, Penarth,

South Wales

P M Smith

ICI Chemical and

Polymers Ltd,

Blackpool, Lancashire

B Bennett

BP Chemicals, Barry, South Wales

D M J Williams

Correspondence to: Dr F I Lee, Department of Gastroenterology, Blackpool Victoria Hospital NHS

Trust, Whinney Heys Road,

FY3 8NR.

Accepted for publication

27 February 1996

\section{Background and Methods}

Vinyl chloride monomer (VCM) was first used in the United Kingdom in the manufacture of polyvinyl chloride (PVC) at ICI Hillhouse in 1940 and at a factory in Barry, operated from 1948 to 1968 by The Distillers' Company, and from then until 1982 by BP Chemicals. VCM had been synthesised by Regnault in 1835 but had a delayed introduction into the chemical industry. It was first used to make rubber substitutes in Germany (1914-1918) but it was not until the 1930s that techniques were devised to polymerise
VCM into stable forms of PVC. It was originally thought to be harmless and was developed as a possible general anaesthetic but was never used following the finding of cardiac arrhythmias in dogs. ${ }^{1}$ A Russian paper describing enlarged tender livers in men who worked with mature and plasticised PVC is much quoted in the context of VCM toxicity but is probably irrelevant. ${ }^{2}$ In 1963 Suciu $^{3}$ described Raynaud's phenomenon and hepatomegaly in workers in a PVC production plant in Rumania and in 1966-1967 there were reports of a syndrome characterised by acro-osteolysis, Raynaud's syndrome, dermal induration, and bone lesions in PVC autoclave cleaners from Belgium, ${ }^{4}$ Britain, ${ }^{5}$ and in the United States. ${ }^{6}$ Following these findings changes were made in the production process and industrially related acro-osteolysis was eliminated. A series of experiments was subsequently set up with rats. ${ }^{78}$ Tumours were demonstrated at various sites after high level exposure. For the first time it was suggested that VCM was an animal carcinogen. In a separate and more comprehensive set of experiments, it was shown that VCM was indeed carcinogenic in animals and that, in particular, angiosarcoma of the liver (ASL) occurred at a range of inhaled concentrations down to 50 parts per million (ppm). ${ }^{9}$ Following recommendations that workers in the industry should be carefully assessed, the observation was made that some workers exposed to vinyl chloride had pronounced changes in the liver including fibrosis. ${ }^{1011}$ The scene was therefore set for the finding in 1974 that three workers involved in the manufacture of PVC had died from ASL in Louisville, Kentucky. ${ }^{12}$ The occurrence of three of these very rare tumours in the same factory provided strong suggestive evidence of causative association. Soon afterwards came reports from the United Kingdom of a retired PVC worker who had died in $1972^{13}$ and

TABLE I Distribution of ASL cases by country as at 12 October $1993^{14}$ 
TABLE II Occupational details of cases of angiosarcoma of the liver in two factories in the United Kingdom (1974-1992)

\begin{tabular}{|c|c|c|c|c|c|c|c|c|c|}
\hline \multirow[b]{2}{*}{ Case $^{\star}$} & \multirow[b]{2}{*}{$\begin{array}{l}\text { Age at } \\
\text { diagnosis (y) }\end{array}$} & \multirow[b]{2}{*}{$\begin{array}{l}\text { Years of } \\
\text { exposure (n) }\end{array}$} & \multirow[b]{2}{*}{$\begin{array}{l}\text { Year of } \\
\text { diagnosis }\end{array}$} & \multirow[b]{2}{*}{$\begin{array}{l}\text { Latency } \\
\text { (years) }\end{array}$} & \multicolumn{5}{|c|}{ Occupational history (years) } \\
\hline & & & & & Polycleaner & Drier & $\begin{array}{l}\text { Autoclave } \\
\text { operator }\end{array}$ & $\begin{array}{l}\text { Polyfloor } \\
\text { worker }\end{array}$ & Other \\
\hline $\mathrm{H} 1 \dagger$ & 71 & $1944-66(22)$ & 1972 & 28 & - & 9 & 13 & - & - \\
\hline B $2 \ddagger$ & 37 & $1966-70(3 \cdot 5)$ & 1974 & 9 & 3.5 & - & - & - & - \\
\hline $\mathrm{H} 3$ & 59 & $1954-72(18)$ & 1979 & 25 & - & 13 & 3 & - & 2 \\
\hline B4 & 65 & $1951-72(21)$ & 1970 & 28 & 2 & 2 & 15 & - & 2 \\
\hline B5 & 48 & $1962-74(12)$ & 1980 & 18 & - & - & 7 & - & 5 \\
\hline B6 & 60 & $1963-71(8)$ & 1980 & 17 & 2 & - & - & - & 6 \\
\hline B7 & 57 & $1950-74(24)$ & 1981 & 31 & - & - & 24 & - & - \\
\hline B8 & 58 & $1950-79(29)$ & 1983 & 33 & - & 4 & - & 17 & 12 \\
\hline B9 & 37 & $1966-70(4)$ & 1984 & 18 & 1 & 1 & - & - & 2 \\
\hline B10 & 57 & $1965-83(16)$ & 1985 & 19 & 3 & - & 13 & - & - \\
\hline H11 & 48 & $1965-83(28)$ & 1985 & 28 & - & - & 26 & - & 2 \\
\hline B12 & 37 & $1968-71(3)$ & 1986 & 18 & 1 & - & 1 & - & 1 \\
\hline B13 & 45 & $1966-77(11)$ & 1987 & 21 & 1 & - & 10 & - & - \\
\hline B14 & 66 & $1956-72(16)$ & 1988 & 32 & 9 & - & - & - & 7 \\
\hline H15 & 66 & $1956-68(12)$ & 1988 & 25 & - & - & 9 & - & 3 \\
\hline H16 & 58 & $1963-88(25)$ & 1989 & 26 & - & - & 25 & - & - \\
\hline B17 & 68 & $1954-80(21)$ & 1992 & 33 & - & - & 21 & - & - \\
\hline B18 & 63 & $1957-74(17)$ & 1992 & 35 & 2 & 3 & 3 & 4 & 7 \\
\hline B19 & 56 & $1965-75(12)$ & 1992 & 35 & 4 & 4 & - & - & 3 \\
\hline B20 & 50 & $1965-75(10)$ & 1992 & 27 & - & 3 & - & - & 7 \\
\hline
\end{tabular}

ॠThese case numbers do not match the case numbers quoted in the International Register of ASL cases. ${ }^{14}$ $\dagger \mathrm{H}=\mathrm{ICI}$ Hillhouse. $\ddagger \mathrm{B}=\mathrm{BP}$ Barry.

another, aged 37 years, dying in $1974,{ }^{14}$ both from ASL. Regular international surveillance since then has yielded 173 cases $^{15}$ (Table I) and it is likely that more will be diagnosed over the next 10 to 20 years or so ${ }^{16}$ despite the industrial measures begun in the 1960s and completed in the 1970 s. This report describes the 20 cases recognised in the United Kingdom by the end of 1994 . These have been confined to two of the seven factories involved in the manufacture of PVC - ICI Hillhouse near Blackpool and British Petroleum, Barry, South Glamorgan.

\section{Results}

Twenty men, aged from 37 to 71 years (mean 54), developed ASL. All had been exposed to VCM for between three and 29 years (mean 15) the tumour developing from nine to 35 years (mean 25) after the first exposure (Table II). (See footnote.)

\section{CLINICAL FEATURES}

\section{Presentation and progress}

In most of these men the presenting features were those of a rapidly enlarging malignant hepatic tumour including abdominal pain (11 cases), abdominal swelling due to ascites (nine cases) and massive hepatomegaly (six cases), oedema (six cases), and severe lethargy (three cases). Two patients were in advanced hepatic failure and only two were significantly jaundiced (Table III).

The mean survival from presentation to death in the 20 workers was 3.5 months (range - 1.5-13) 11 living for three months or less. Seventeen died from hepatic failure with encephalopathy, precipitated by haemorrhage from oesophageal varices in two and from large duodenal ulcers in two. In three men severe intraperitoneal haemorrhage occurred and in two of these it was the immediate cause of death. At necropsy it was found that tumour

TABLE III Clinical details and progress of cases of angiosarcoma in the United Kingdom (1974-1992)

\begin{tabular}{|c|c|c|c|c|}
\hline Case & $\begin{array}{l}\text { Age at } \\
\text { diagnosis (y) }\end{array}$ & Presenting features & Progress and mode of death & $\begin{array}{l}\text { Survival from time } \\
\text { of presentation } \\
\text { (months) }\end{array}$ \\
\hline $\begin{array}{l}\mathrm{H} 1 \\
\mathrm{~B} 2\end{array}$ & $\begin{array}{l}71 \\
37\end{array}$ & $\begin{array}{l}\text { Oedema, ascites, pain, hepatomegaly } \\
2 \text { years laparotomy for duodenal ulcer. } \\
\text { Jaundice, ascites, peliosis }\end{array}$ & $\begin{array}{l}\text { Hepatic coma } \\
\text { Ascites, anaemia, hepatic coma, jaundice }\end{array}$ & $\begin{array}{l}1 \cdot 5 \\
4 \cdot 0\end{array}$ \\
\hline $\begin{array}{l}\text { H3 } \\
\text { B4 } \\
\text { B5 }\end{array}$ & $\begin{array}{l}59 \\
65 \\
48\end{array}$ & $\begin{array}{l}\text { Pain, hepatomegaly } \\
\text { Lethargy, oedema, ascites } \\
6 \text { years varices. Non-cirrhotic portal } \\
\text { hypertension, ascites, oedema }\end{array}$ & $\begin{array}{l}\text { Bleeding varices, ascites, hepatic coma } \\
\text { Hepatic coma, hepatorenal syndrome } \\
\text { Intraperitoneal haemorrhage (tumour) }\end{array}$ & $\begin{array}{l}4 \cdot 0 \\
1 \cdot 0 \\
0 \cdot 0\end{array}$ \\
\hline B6 & 60 & $\begin{array}{l}10 \text { years non-cirrhotic portal } \\
\text { hypertension. Liver failure }\end{array}$ & Hepatic coma, haemorrhage from DU & $1 \cdot 0$ \\
\hline $\begin{array}{l}\text { B7 } \\
\text { B8 }\end{array}$ & $\begin{array}{l}57 \\
58\end{array}$ & $\begin{array}{l}\text { Anorexia, lethargy, ascites } \\
\text { Abdominal pain, weight loss }\end{array}$ & $\begin{array}{l}\text { Hepatic coma } \\
\text { Cerebral haemorrhage (metastatic } \\
\text { angiosarcoma) }\end{array}$ & $\begin{array}{l}1 \cdot 0 \\
0 \cdot 5\end{array}$ \\
\hline $\begin{array}{l}\text { B9 } \\
\text { B10 } \\
\text { H11 } \\
\text { B12 } \\
\text { B13 } \\
\text { B14 } \\
\text { H15 }\end{array}$ & $\begin{array}{l}37 \\
57 \\
48 \\
38 \\
46 \\
67 \\
66\end{array}$ & $\begin{array}{l}\text { Abdominal pain } \\
\text { Jaundice, oedema, ascites } \\
\text { Abdominal pain, hypercalcaemia } \\
\text { Abdominal pain } \\
\text { Anorexia, lethargy, abdominal pain } \\
\text { Abdominal pain, back pain } \\
13 \text { years non-cirrhotic portal } \\
\text { hypertension. Pain, ascites }\end{array}$ & $\begin{array}{l}\text { Hepatic coma } \\
\text { Bleeding varices, hepatic coma } \\
\text { Intraperitoneal haemorrhage (tumour) } \\
\text { Hepatic coma } \\
\text { Anaemia, hepatic coma } \\
\text { Hepatic coma } \\
\text { Hepatic coma }\end{array}$ & $\begin{array}{r}1 \cdot 0 \\
0 \cdot 5 \\
7 \cdot 0 \\
6 \cdot 0 \\
13 \cdot 0 \\
6 \cdot 0 \\
2 \cdot 0\end{array}$ \\
\hline H16 & 57 & $\begin{array}{l}\text { Lethargy, weight loss, oedema, } \\
\text { hepatomegaly }\end{array}$ & Hepatic coma & $3 \cdot 0$ \\
\hline B17 & 68 & Weight loss, oedema, jaundice & $\begin{array}{l}\text { Intraperitoneal haemorrhage, perforated } \\
\text { DU. Hepatic coma }\end{array}$ & $4 \cdot 0$ \\
\hline $\begin{array}{l}\text { B18 } \\
\text { B19 } \\
\text { B20 }\end{array}$ & $\begin{array}{l}63 \\
56 \\
50\end{array}$ & $\begin{array}{l}\text { Lethargy, abdominal pain, ascites } \\
\text { Abdominal pain } \\
8 \text { years non-cirrhotic portal } \\
\text { hypertension. Pain, diarrhoea }\end{array}$ & $\begin{array}{l}\text { Hepatic coma } \\
\text { Hepatic coma } \\
\text { Hepatic coma }\end{array}$ & $\begin{array}{l}5 \cdot 0 \\
7 \cdot 0 \\
3 \cdot 0\end{array}$ \\
\hline
\end{tabular}


TABLE IV Results of selected laboratory tests in cases of angiosarcoma of the liver

\begin{tabular}{ll}
\hline Test (normal range) & Results \\
\hline Platelets $\left(150-400 \times 10^{9} / 1\right)$ & $61-440(6 / 20$ low $)$ \\
Bilirubin $(3-17 \mu \mathrm{mol} / 1)$ & $7-281(9 / 20 \mathrm{high})$ \\
Alkaline phosphatase $(30-125 \mathrm{IU} / \mathrm{l})$ & $75-714(19 / 20 \mathrm{high})$ \\
GGT $(0-48 \mathrm{IU} / 1)$ & $46-305(19 / 20 \mathrm{high})$ \\
AST $(7-40 \mathrm{IU} / 1)$ & $21-210(9 / 20 \mathrm{high})$ \\
Albumin $(30-52 \mathrm{~g} / 1)$ & $21-45(8 / 20$ low $)$ \\
\hline
\end{tabular}

nodules had ruptured spontaneously. In 17 cases there was no evidence of metastases at necropsy. One man had hypercalcaemia with no metastases. All livers were the site of the primary ASL. In four cases there was a previous history of variceal haemorrhage secondary to non-cirrhotic portal hypertension.

\section{Laboratory findings}

Routine haematological and biochemical tests were carried out on all patients at the time of presentation. The most common findings were in the serum alkaline phosphatase (ALP) and $\gamma$ glutamyl transferase enzymes (GGT), which were increased above the normal range in 17 of 20 cases (Table IV). Abnormalities of platelet count, serum bilirubin, aspartate transaminase (AST), and albumin occurred in less than 50\% of patients. In one man, serum calcium was raised (case $\mathrm{H} 11$ ) and this is discussed below.

\section{Radiology}

(1) Isotope scans were carried out in six cases. All showed non-specific findings consisting of a diffusely abnormal pattern with obvious filling defects.

(2) Diffuse liver abnormalities and enlargement were reported in 13 available ultrasound examinations. All showed liver enlargement with a severely abnormal pattern and one or more large lesions within the liver compatible with malignant tumour.

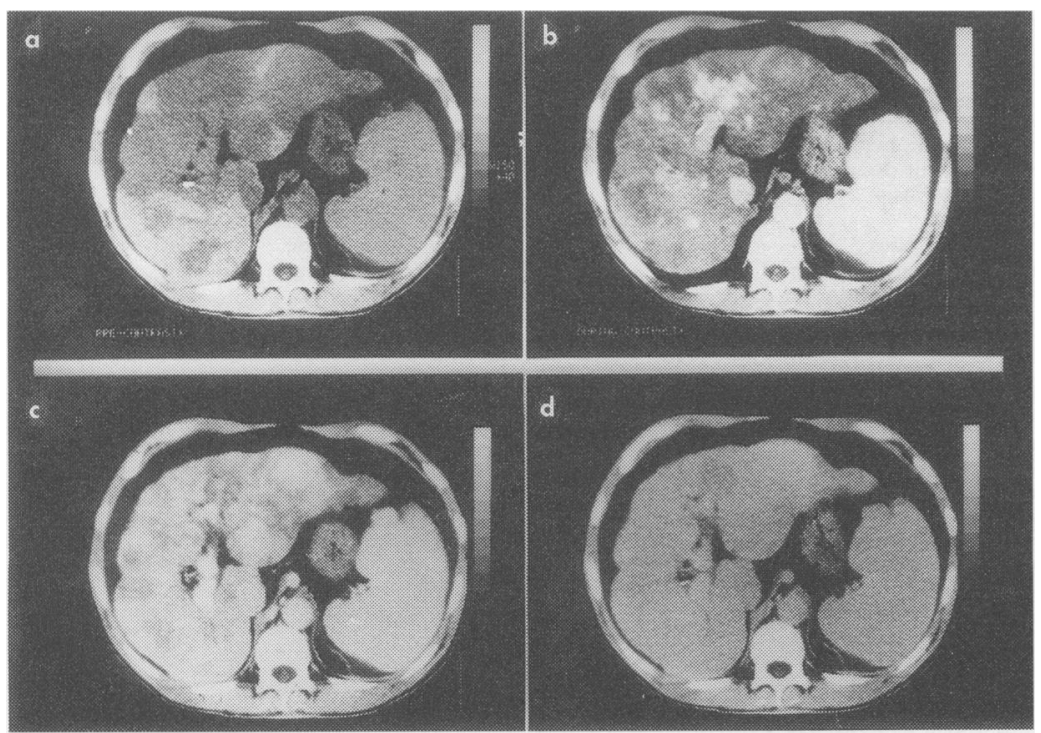

Figure 1: Computed tomography of liver (case B20). (a) Non-enlarged scan through upper abdomen showing multifocal hypodense tumour masses in both liver lobes. (b) Foci of enlargement in the tumour during dynamic contrast. (c) One minute after injection of contrast. Some parts of the tumour are hyperdense compared with normal liver. (d) Six minutes after injection, the tumour is now isodense compared with surrounding liver.
(3) Computed tomograms were available in seven patients. All showed liver enlargement with a severely abnormal pattern and tumour masses (Figs 1 and 2).

(4) Hepatic arteriography was carried out in four patients demonstrating an obvious tumour circulation in all cases. In two of these the abnormality was limited to the right lobe.

Radiological findings supported the clinical diagnosis without providing unequivocal confirmation.

\section{Liver biopsy}

In only nine cases was an attempt made in life to confirm the clinical diagnosis histologically. Five had needle biopsy performed (cases $\mathrm{H} 1$, B4, B5, B9, and B14). In four of these the hepatic tissue showed clear cut changes of ASL. In the fifth patient (H1) there were minor non-specific inflammatory changes in the portal tracts but no evidence of tumour. One man (case B5) suffered a major intraperitoneal haemorrhage and died the next day. Postmortem examination showed the bleeding to have been from spontaneous rupture of a large vascular haemorrhagic tumour occupying most of the right hepatic lobe close to but separate from the biopsy site (Fig 3). Four men underwent laparotomy and wedge biopsy to reduce the likelihood of sampling errors in needle biopsy material. In three the specimens were diagnostic of angiosarcoma $(\mathrm{H} 3, \mathrm{H} 11$, and B13) but not in case B12. In 11 cases no attempt at a histological diagnosis was made in life. In most of these the combination of the occupational history and the clinical picture led to a presumptive diagnosis of ASL; in these very ill patients the discomfort and risks of liver biopsy were not thought to be justified.

In four men a liver biopsy (two needle, two laparotomy) had been carried out six to 18 years before their terminal illness. All had presented with evidence of portal hypertension. In each the histological changes were of non-cirrhotic portal fibrosis. ${ }^{17}$

\section{Metastases}

In only three of 20 cases had metastases occurred. One patient died following intracranial haemorrhage from cerebral metastases (case B8). In one there was spread of tumour through the diaphragm into the right pleura (case $\mathrm{H16}$ ) and in another a large metastasis was found in the right adrenal gland at necropsy (case B13).

\section{Non-metastatic manifestation of malignancy} hypercalcaemia

Case H11, a 48 year old man, had no detectable tumour spread but had hypercalcaemia at presentation. Initial symptoms were severe right upper quadrant pain and lethargy. On examination he had a hard irregular liver extending $5 \mathrm{~cm}$ below the costal margin. An isotope liver scan showed a large hepatic tumour, confirmed by a hepatic arteriogram that showed the right hepatic artery 


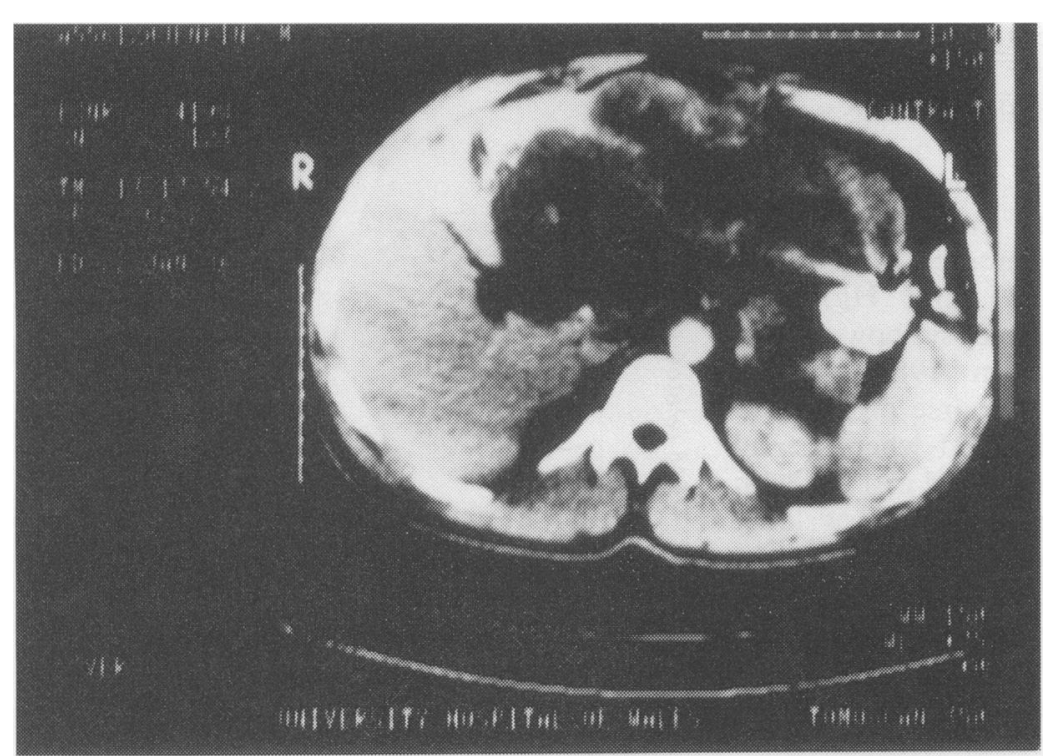

Figure 2: Computed tomography of liver during dynamic phase of contrast injection to show huge mass in left lobe of liver (case B12).

splayed around the tumour with a pathological peripheral circulation. In later films the contrast outlined venous pools. The serum ALP was $350 \mathrm{IU} / 1$ and the serum calcium was $3 \cdot 14$ $\mathrm{mmol} / \mathrm{l}$ with a phosphate level of $0.70 \mathrm{mmol} / \mathrm{l}$. At laparotomy there was a large vascular tumour in the right lobe of the liver. Histological examination showed the typical appearances of angiosarcoma. The patient received adriamycin $100 \mathrm{mg}$ and cyclophosphamide $1 \mathrm{~g}$ intravenously at monthly intervals. Initially the serum calcium fell to normal, but after four weeks it had risen to $3.13 \mathrm{mmol} / \mathrm{l}$. Prednisolone $30 \mathrm{mg}$ daily was given orally but there was little response and death occurred eight months after diagnosis.

\section{Preceding non-cirrhotic portal hypertension (four cases) \\ Four men (B5, B6, H15, B20) were especially interesting in that they were shown to have portal hypertension six to 13 years before the diagnosis of ASL of the liver was established.}

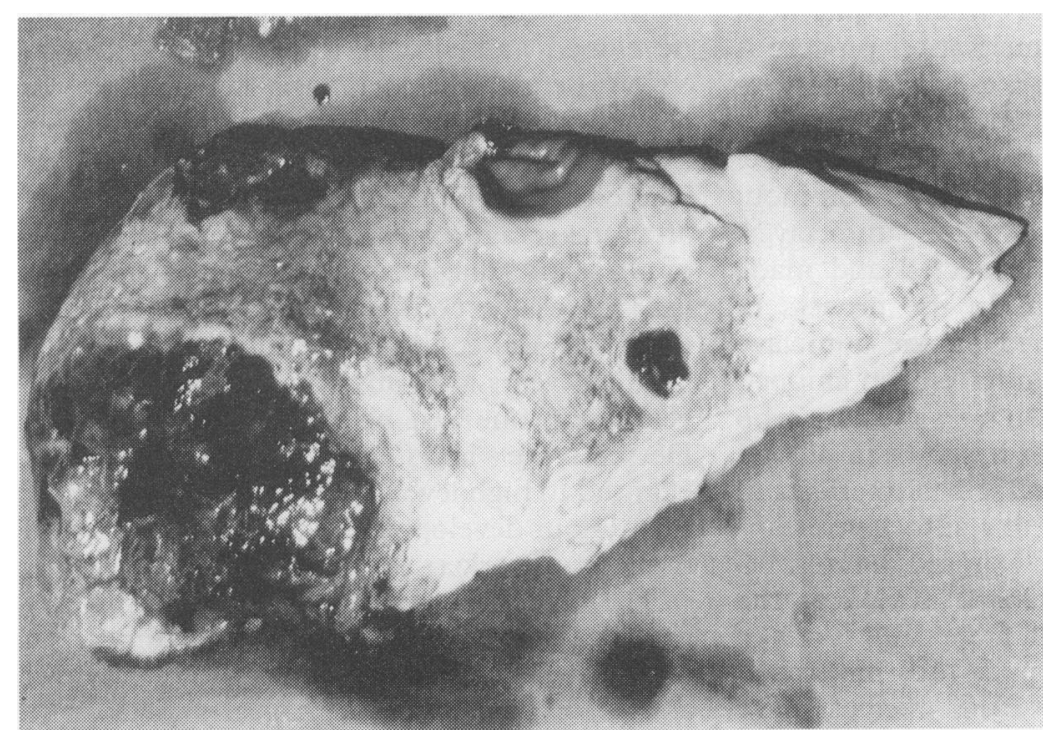

Figure 3: View of right lobe of liver showing spontaneous rupture of angiosarcoma (case B5).
Patient B5 was found to have thrombocytopoenia during a factory screening programme of process workers in $1974 .{ }^{17}$ Further investigations showed hypersplenism, presinusoidal hypertension, and oesophageal varices. A needle biopsy of the liver showed slight portal fibrosis. Five years later in 1979 he had a large gastrointestinal haemorrhage from oesophageal varices. This was controlled by injection sclerotherapy but three months later ascites and oedema developed. He died after a liver biopsy and necropsy demonstrated several small haemorrhagic liver tumours and a large deposit in the right lobe that had ruptured into the peritoneum.

A 49 year old man (B6) was found to have hepatomegaly while being assessed for an irritant rash in 1969. Further investigation showed splenomegaly, oesophageal varices, a patent portal vein at splenic venogram, and a raised splenic pulp pressure $(205 \mathrm{~mm}$ of blood). He was known to have worked in the production of PVC for eight years from 19631971. In 1970 he had a portacaval shunt following a haematemesis. The liver looked pale, nodular, and 'cirrhotic' but operative liver biopsy showed non-cirrhotic fibrosis. In 1980 he was admitted to hospital with hepatic precoma. He improved initially but lapsed into a coma. Gastroscopy showed insignificant varices, a large volume of blood in the stomach, and a duodenal ulcer. Three round areas in the posterior part of the right hepatic lobe had the appearance of malignant deposits. $\mathrm{He}$ died a few days later in hepatic coma. At postmortem examination the death was attributed to bronchopneumonia. The liver was small $(1130 \mathrm{~g})$ and fibrotic. There were several tumours one of which was haemorrhagic. Many of the tumours were well differentiated but elsewhere there were areas of ASL with a great variety of liver cell lesions.

Case $\mathrm{H} 15$ presented in 1974, aged 52 years, with oedema and ascites. He was known to have worked in the PVC industry since 1963. There were minor changes in the liver function tests and a low serum albumin $(28 \mathrm{~g} / \mathrm{l})$. He declined further investigations. One year later he presented with massive upper gastrointestinal bleeding from large oesophageal varices, and a high splenic pulp pressure $(32 \mathrm{~mm} \mathrm{Hg}$ ) was found. A portacaval shunt was performed but further bleeding occurred after a month and a lienorenal shunt was carried out. A liver biopsy showed capsular, portal, and interlobular fibrosis but no cirrhosis. There were no further episodes of bleeding but he had continuing ascites and recurrent portal-systemic encephalopathy. In 1988 he was admitted with severe abdominal pain and a raised serum amylase $(>2000 \mathrm{U} / \mathrm{l})$ compatible with the diagnosis of acute pancreatitis. Hepatic enlargement was noted and an ultrasound examination was reported as showing diffuse changes in the liver suggestive of malignancy. $\mathrm{He}$ deteriorated with increasing abdominal pain and ascites. He lapsed into hepatic coma and died. At necropsy the liver was not enlarged $(1450 \mathrm{~g})$ with a coarse nodular appearance. There were areas of haemorrhagic 
tumour in both lobes identified as ASL histologically.

Another man (case B20) was exposed to VCM from 1965-1974. As part of a screening programme in 1974 he was found to have a low platelet count $\left(61 \times 10^{9} / 1\right)$. Investigation showed him to have splenomegaly, a raised splenic pulp pressure $(29 \mathrm{~mm} \mathrm{Hg})$, and oesophageal varices. Liver biopsy showed noncirrhotic portal fibrosis. In 1982 he had melaena and underwent a course of injection sclerotherapy and again in 1991 when a small varix was found. He re-presented in 1992 with abdominal pain, diarrhoea, and ankle swelling. Biochemical tests showed: serum bilirubin 71 $\mu \mathrm{mol} / \mathrm{l}$, ALP $176 \mathrm{IU} / \mathrm{l}$. Ultrasound and computed tomography showed splenomegaly and a severely abnormal liver suggestive of ASL. He responded briefly to treatment but he died after three months. At postmortem examination the liver weighed $3970 \mathrm{~g}$ and was almost completely replaced by a haemorrhagic ASL. The spleen was large $(980 \mathrm{~g})$ and there were numerous varices surrounding the lower oesophagus although the submucosal varices had all been obliterated by sclerotherapy.

\section{Discussion}

Seven factories producing PVC have been set up in the United Kingdom, but in only two, BP Barry (15 cases) and ICI Hillhouse (five cases), have cases of ASL occurred, between 1972 and 1992 (Fig 4). The extreme rarity of this tumour made it easier to recognise the relation to VCM exposure. It has been calculated that the background level of ASL incidence in the UK is between two and seven cases per year. ${ }^{18}$ This does not include cases attributable to VCM exposure to Thorotrast, the other established aetiological agent. ${ }^{19}$

In the older plants VCM exposure levels were high, but since 1975 operators have been exposed to low levels of VCM. Modern plants are situated in the open air with no confinement within buildings. All chemicals made and used are totally enclosed within the plant and escape of chemicals into the air has for a long time been small, except when equipment failure occurs. The polymerisation process is carried out in large autoclaves at temperatures between 40 and $80^{\circ} \mathrm{C}$ under pressure. In earlier days, autoclaves were $1-25 \mathrm{~m}^{3}$ in size. Today 40-80 $\mathrm{m}^{3}$ autoclaves are common; some companies use up to $200 \mathrm{~m}^{3}$ autoclaves. The empty autoclave is inspected and made ready for the next batch. In the process of making PVC, scale formed on the autoclave wall. Previously this would have been chipped off manually after every batch by a worker who entered the autoclave after it had been purged with air. Many of the adverse health effects in the past can be traced to this autoclave cleaning process. Workers were exposed to intermittent, intense concentrations of VCM as the autoclave was opened, when concentrations of VCM as high as $10000 \mathrm{ppm}$ may have been encountered. Improved PVC recipes have decreased the scale formation, and high pressure water cleaning the necessity and

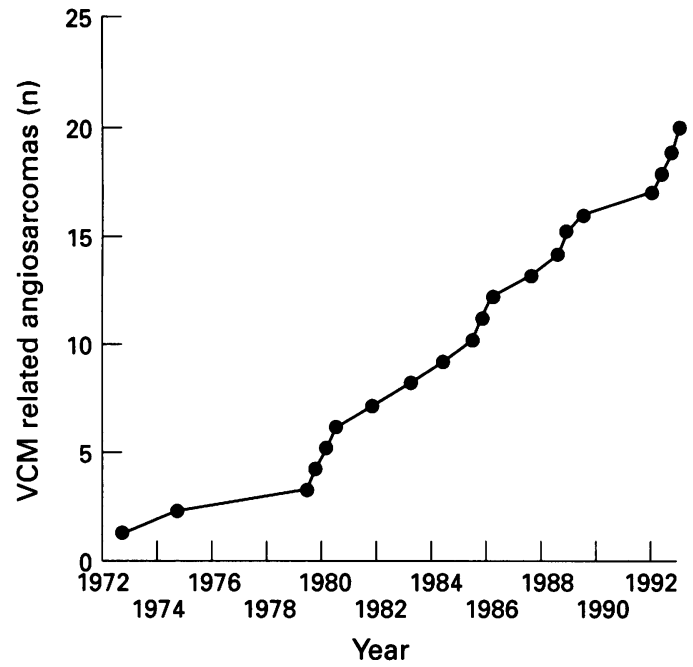

Figure 4: UK cumulative total of VCM related angiosarcomas 1974-1995.

frequency of manual cleaning. Autoclave cleaning is now carried out under very different conditions from those previously outlined. Equipment and manufacturing methods have been changed to give improved ventilation, sensitive analytical methods have been elaborated, and low permissible concentrations have been established with regular monitoring. The plants are now monitored on a continuous basis, using a Computer Operated Multi-Point Analyser, which analyses 24 points fixed in the plant. Further support is given through personal monitoring on a weekly basis.

All the people who developed ASL were exposed to high levels of VCM except one who worked as a premix, blowdown, and stripping operator. This worker had medium exposure, but this would still have been in the region of $200 \mathrm{ppm}$. Of the remaining 19 workers, the principal occupations were; autoclave operators (13) and poly cleaners (11). Some men had done both jobs. Our patients were in contact with VCM for seven to 31 years, before the 1975 strict Code of Practice was introduced, and many process workers would have inhaled concentrations of $1000 \mathrm{ppm}$ on occasions.

There were differences between the two factories with regard to the age at which ASL developed and also in the exposure time to VCM before the diagnosis was made. In general workers developed the condition after shorter exposure and at a younger age at Barry where the age range was from 37 to 67 years after an average exposure of 14 years and in 10 of these the diagnosis was made at aged 58 years or less. In contrast in the five cases at ICI Hillhouse the condition developed from aged 48 to 71 years after an average exposure of 21 years, only one case being under 58 years old. Despite the large number of employees exposed to high levels of VCM before 1973-74 the tumour developed in a comparatively small number of workers.

The diagnosis should be considered in any past or present VCM worker presenting with hepatomegaly, abdominal pain, malaise, ascites or bleeding oesophageal varices. The tumours are usually large and evident on ultrasound or computed tomography. Ultrasound 
will show changes suggestive of ASL, and may also show evidence of portal hypertension. The technique, however, will not detect noncirrhotic portal fibrosis where even a liver biopsy may be normal. ${ }^{20}$ Again the computed tomographic appearances of ASL are nonspecific but are consistent with a vascular tumour, the differential diagnosis including benign vascular tumours, other primary malignant tumours such as hepatocellular carcinoma, and vascular metastases. ${ }^{21}$ In difficult cases angiography is helpful, ${ }^{22}$ showing typical vascular abnormalities. Histological confirmation was available prior to necropsy in only seven of 20 cases, in four from material obtained at needle biopsy and in three from open liver biopsy at laparotomy. One patient died after needle biopsy and we would urge caution with this technique. In one study $16 \%$ of patients bled after needle biopsy. ${ }^{23}$

Liver damage had been noted in VCM workers before the recognition of ASL. ${ }^{1011}$ Non-cirrhotic portal fibrosis follows activation of the presinusoidal lipocytes (Ito cells) by VCM. It leads to presinusoidal hypertension, splenomegaly, and bleeding varices, and may be associated with an inconspicuous portal fibrosis. ${ }^{20}$ At the initial time of reporting the first seven cases, only one had developed ASL ${ }^{17}$ but with the passage of time three more have developed the tumour, presumably because of an effect of VCM on the anatomically adjacent endothelial cell. In two factory surveys of $487^{24}$ and 422 workers ${ }^{25}$ liver function tests proved to have no value in detecting liver disorders, but two employees who were picked out because of thrombocytopenia due to portal hypertension and hypersplenism later went on to develop ASL. We suggest that patients with non-cirrhotic portal fibrosis secondary to VCM exposure should undergo lifelong follow up. Even for workers without evidence of liver damage, there is a latent interval of 12-29 years (mean 21) from first exposure to the development of ASL. Health surveillance at the present levels of exposure is not effective in prolonging the life of the work force from ASL, but does allow workers to discuss their concerns, reducing stress and anxiety created by working with a human carcinogen. After a study of a large number of workers exposed to VCM in the United States it was concluded that the current clinical, biochemical, and haematological tests were of limited value in predicting ASL, but may be of value in predicting other hepatotoxic effects. ${ }^{26}$

The pathological findings in patients with ASL are characteristic. The liver capsule may be irregularly thickened from fibrosis. Liver enlargement is usual, often massive, but in a few cases longstanding fibrotic change may limit the degree of hepatomegaly. Haemorrhagic nodules of varying size are present in the liver along with non-cirrhotic fibrosis in much of the tissue not involved with tumour. None of the patients in this series had cirrhosis. As indicated above there were four cases of severe non-cirrhotic portal fibrosis and in addition one liver showed peliosis (case B2) similar to that seen with anabolic steroids. Three basic histological patterns may be seen in different parts of the tumour. ${ }^{27} 28$ The most common is the sinusoidal pattern in which dilated hepatic sinusoids are lined with enlarged proliferating cells with easily recognisable hepatocyte plates; the second most common is papillary in which papillary formations of tumour cells are borne on a core of connective tissue that may include recognisable surviving hepatocytes containing inspissated bile pigment. The cavernous pattern is characterised by large blood filled spaces surrounded by thick fibrotic cords lined by tumour cells. The tumours are multicentric and death occurs in most cases before distant metastases appear. The cells involved in these tumours may be difficult to distinguish from reactive cells or they may be quite unusual showing irregular, bizarre giant cells forms. A helpful diagnostic feature is their close relation to hepatocyte plates and obvious blood filled spaces. The cells are endothelial in origin as shown by the presence of factor VIII, an endothelial cell marker. ${ }^{29}$ The pathological features of hepatic angiosarcoma do not indicate the cause of the disease; environmental causes such as vinyl chloride, arsenic, and Thorotrast produce the same changes as in cases with no known aetiological agent. ${ }^{30}$

Treatment of this tumour is difficult. In one study ${ }^{31}$ three of four patients had a transient response to adriamycin combined with cytoxan or methotrexate. Liver transplantation is rarely possible as the tumours are large, multifocal, and rapidly enlarging at the time of diagnosis. Transplantation for non-cirrhotic portal hypertension is not warranted as some of these cases do not develop ASL.

Any method to assess the expected number of new cases will probably be an imprecise exercise. In the absence of complete information on the people exposed to VCM, projections may be based on the distribution of cases that have occurred within different periods of maximum possible latency. ${ }^{16}$ By this method it has been predicted that a total of 25-27 cases of ASL may occur at BP Barry and six to seven at ICI Hillhouse.

We are grateful to Dr Hayden Adams, Consultant Radiologist, Llandough Hospital for the computed tomographic examinations and to Dr David Montgomery, Consultant Radiologist, Blackpool Victoria Hospital for the arteriogram.

1 Oster JC, Robert H, Carr CJ, Kranz JC. Narcosis with vinylchloride. Anesthesiology 1949; 8: 358-61.

2 Tribukh SL, Tikhomirova NP, Levina SV, Koslov LA. Working conditions and measures for their improvement in the production and use of vinyl chloride plastics. Gig in the production and
Sanit $1949 ; 14: 38-44$

3 Suciu I, Drejman I, Valaskai M. Etudes des maladies dues chlorure vinyle. Med Lav 1967; 58: 447-52.

4 Cordier JM, Fievez C, Lefevre MJ, Sevrin A. Acro-osteolyse et lesions cutanées associées chez deux ouvriers affectes au nettoyage d'autoclaves. Cahiers de Medecine du Travai 1966; 4: 1-39.

5 Harris DK, Adams WGF. Acro-osteolysis occurring in men engaged in the polymerization of vinyl chloride. $B M \mathcal{F}$ 1967; 3: 712-4

6 Wilson RH, McCormick WE, Tatum WA, Creech JL Jr. Occupational acreo-osteolysis. $\mathscr{f} A M A$ 1967; 201: 83-7. Viola P. Pathology of vinyl chloride. Med Lav 1970; 61: 174-80.

8 Viola P, Bigotti A, Caputo A. Oncogenic response of rat skin, lungs and bones to vinyl chloride. Cancer Res 1971; 31: $516-22$.

9 Maltoni C, Lefermine C. Carcinogenicity bioassays of vinyl chloride. Current results. Ann NY Acad Sci 1975; 271: chloride.

10 Lange CE, Juhe S, Stein G, Veltman G. Vinyl chloride disease - an occupational system sclerosis? Int Archiv fur Arbeitzmedizen 1974; 32: 1-31. 
11 Marsteller HJ, Lelbach WK, Muller R, Juhe S, Lange CE, Rohner HG, et al. Chronic toxic liver damage in workers on PVC production. Dtsch Med Wochensch 1974; 198: 2311-4

12 Creech JL Jr, Johnson MN. Angiosarcoma of the liver in the manufacture of polyvinyl chloride. F Occup Med 1974; 16: $150-1$.

13 Lee FI, Harry DS. Angiosarcoma of the liver in a vinyl chloride worker Lancet 1974; i: 1316-8.

14 Smith PM, Williams DMJ, Evans DM. Hepatic angiosarcoma in a vinyl chloride worker. Bull NY Acad Med 1976; 52: 447-52.

15 Drion F. Association of Plastic Manufacturers in Europe (APME). Register of cases of angiosarcoma of the liver (ASL). Brussels: 1993.

16 Forman D, Bennett B, Stafford J, Doll R. Exposure to vinyl chloride and angiosarcoma of the liver. A report of the register of cases. BMf 1985; 42: 750-3.

17 Smith PM, Crossley IR, Williams DMJ. Portal hypertension in vinyl chloride workers. Lancet 1976; ii: 602-6.

18 Baxter PJ, Anthony PP, MacSween RNM, Scheuer PJ. Angiosarcoma of the liver; incidence and aetiology in Great Britain. Br f Ind Med 1980; 37: 213-21.

19 MacMahon HE, Murphy AS, Bates ML. Endothelial cell sarcoma of the liver following Thorotrast injections in sarcoma of the liver following Thorotrast in
Great Britain. Am $\mathcal{F}$ Pathol 1947; 23: 585-611.

20 Blendis LM, Smith PM, Lawrie BW, Stephens MR, Evans WD. Portal hypertension in vinyl chloride monomer workers. Haemodynamic study. Gastroenterology 1978; 75: 206-11.

21 White PG, Adams H, Smith PM. The computed tomographic appearances of angiosarcoma of the liver. Clin Radiol 1993; 48: 321-5.
22 Whelan JG, Creech JL Jr, Tamburro CH. Angiographic and radionuclide characteristics of hepatic angiosarcoma found in vinyl chloride workers. Radiology 1976; 118: 549-57.

23 Locker GY, Doroshow JH, Zwelling LABA. The clinical features of angiosarcoma: a report of four cases and a review of the English literature. Medicine 1979; 58: 48-63.

24 Williams DMJ, Smith PM, Taylor KJW, Crossley IR, Duck BW. Monitoring liver disorders in vinyl chloride monomer workers using greyscale ultrasonography. $\mathrm{Br} \mathcal{F}$ Ind Med 1976; 33: 152-7.

25 Lee FI, Harry DS, Adams WGF, Litchfield M. Screening for liver disease in vinyl workers. Br $₹$ Ind Med 1977; 34: for liver

26 Tamburro $\mathrm{CH}$. The hepatic role of carcinogenesis and its early detection: the vinyl chloride model. Yale f Biol Med 1978; 51: 67-80.

27 Thomas LB, Popper H, Berk P, Selikoff LJ, Falk H. Vinyl chloride induced liver disease. $N$ Engl f Med 1975; 292 447-52.

28 Weinbren $\mathrm{K}$. Histopathology of lesions associated with exposure to vinyl chloride monomer. Proc $R$ Soc $\mathrm{Med}$ 1976; 69: 299-303.

29 Fortwengler HP Jr, Jones J, Espinosa E, Tamburro $\mathrm{CH}$ Evidence of endothelial origin of vinyl chloride induced
hepatic angiosarcoma. Gastroenterology 1981; 80: 1415-9.

30 Popper H, Thomas LB, Telles NC, Falk H, Selikoff LJ. Popper H, Thomas LB, Telles NC, Falk H, Selikoff LJ.
Development of hepatic angiosarcoma in man induced by vinyl chloride, thorotrast and arsenic. Am $\mathcal{F}$ Pathol 1978; 92: 349-68.

31 Dannaher A, Tamburro CH, Yam LT. Chemotherapy of vinyl chloride associated angiosarcoma. Cancer 1981; 47: 466-9. 